\title{
An audit of extra-uterine pregnancy in a tertiary care facility in Northern India
}

\author{
Sheeba Marwah ${ }^{1}$, Kumari Usha Rani ${ }^{2 *}$, Archana Mishra ${ }^{2}$ \\ ${ }^{1}$ Department of Obstetrics and Gynecology, NDMC Medical College and Hindu Rao Hospital, New Delhi, India \\ ${ }^{2}$ Department of Obstetrics and Gynecology, VMMC and Safdarjung hospital, New Delhi, India
}

Received: 29 August 2017

Accepted: 25 September 2017

\author{
*Correspondence: \\ Dr. Kumari Usha Rani, \\ E-mail: usharani10066@yahoo.com
}

Copyright: (C) the author(s), publisher and licensee Medip Academy. This is an open-access article distributed under the terms of the Creative Commons Attribution Non-Commercial License, which permits unrestricted non-commercial use, distribution, and reproduction in any medium, provided the original work is properly cited.

\begin{abstract}
Background: Ectopic pregnancy is the most frequent lethal gynaecological predicament, befalling worldwide in all strata of reproductive women. It remains the leading cause of pregnancy-related first trimester deaths. Though prompt diagnosis has furthered a decline in associated morbidity, an upsurge has been seen in its prevalence owing to a rise in predisposing risk factors. The objectives of this study were to identify incidence, risk factors, and outcome in patients presenting with ectopic pregnancy in a tertiary care hospital.

Methods: This two-year retrospective study was conducted in Department of Obstetrics and Gynecology in Vardhaman Mahavir Medical College and Safdarjung hospital, on patients presenting with a diagnosis of ectopic pregnancy (either ruptured or un-ruptured). The primary outcome was incidence of ectopic pregnancy. Secondary outcomes noted were demographic characteristics, predisposing risk factors, clinical presentation and management course in hospital. Data was recorded on a predesigned proforma and deciphered later.

Results: Incidence of ectopic pregnancy was $0.82 \%$. Significant causative factors were previous history of PID (29.28\%), TB (21.4\%), previous pelvic surgeries (18.57\%) and preceding ectopic pregnancy (12.14\%).

Conclusions: Increase awareness and knowledge of risk factors amenable to modification and features will aid early diagnosis of extra-uterine pregnancy, besides planning conservative treatment if possible, and devising effective riskreduction strategies.
\end{abstract}

Keywords: Audit, Clinical outcome, Ectopic gestation, Risk factors, Trends, Tertiary hospital

\section{INTRODUCTION}

Gynaecological emergencies form a gargantuan amount of the workload of an obstetrician. ${ }^{1}$ Appropriate management of these have evolved over the period of time because of evidence-based medicine coalesced with a virtuous clinical assessment. All primary health care doctors ought to be well versed with skills to diagnose such emergencies in women for prompt referral to higher centres.

Ectopic pregnancy, the implantation of a fertilized ovum outside the uterine cavity, is one of the most common life threatening surgical gynecological emergency occurring across all races, countries and socio-economic class of women during the reproductive years. It accounts for $2 \%$ of all pregnancies. ${ }^{2-4}$ It remains the leading cause $(9 \%)$ of pregnancy-related first trimester deaths worldwide., ${ }^{4,5}$ Prompt diagnosis has furthered to a decline in associated morbidity.

It is recurrent in nearly $20 \%$ of patients and leads to permanent sterility in $20 \%$ to $60 \%$ of cases. ${ }^{2-4}$ There has been an upsurge in its prevalence because of increase in the incidence of the risk factors predisposing to ectopic pregnancy especially ovulation stimulation as in artificial reproductive techniques, pelvic infection and tubal surgeries. ${ }^{6-8}$ 
Nearly $97 \%$ of all ectopic pregnancies are implanted within the fallopian tube owing to the presence of a fallopian tube pathology like genital tract infection (gonorrhoea and chlamydia), tubal surgery including tubal sterilization, previous ectopic pregnancy, and in utero exposure to diethylstilbestrol. ${ }^{9,10}$

Other risk factors for tubal ectopic gestation include smoking, conception with an intrauterine device (IUD) in situ or while using a progesterone only contraceptive method. ${ }^{7-11}$ Despite these known risk factors, the causes of most ectopic gestation still remain elusive. ${ }^{12,13}$

Classically, the diagnosis is based on triad of a history of pelvic pain associated with amenorrhoea, a positive pregnancy test with or without slight vaginal bleeding. ${ }^{5,6,12,13}$ However, they can vary from no initial definitive physical findings to symptoms of rupture like Severe pelvic pain, shoulder pain, syncope, nausea and vomiting, back pain, urge to empty the bowel, associated with pallor and signs of shock along-with cervical motion/ forniceal tenderness and fullness in the pouch of Douglas. ${ }^{14}$

Ectopic pregnancy can be diagnosed before rupture by measuring serial human chorionic gonadotropin (HCG) levels and using serial ultrasonography. ${ }^{14,15}$

Recently medical and expectant management have been added in the clinical armamentarium of an obstetrician for selected cases which would assist in decreasing the unnecessary burden on health facilities. ${ }^{16,17}$

Nevertheless, high index of suspicion besides early diagnosis, aggressive surgical management when required, and adequate blood replacement would be instrumental in preventing maternal death in most of the cases.

Most conjectures of ectopic pregnancy, come from studies with either risk factors or outcome. ${ }^{18-20}$ These have recommended that examination of epidemiologic patterns and details of the presentation and clinical course of ectopic gestation, besides comprehensive analysis of risk factors along-with them would aid a long way in preventing morbidity due to this condition in today's time. ${ }^{18-21}$

Keeping in view this backdrop, the extant study was proposed to analyse the patients presenting with ectopic pregnancy in a tertiary level hospital to find out the trends, and establish where we are standing in modern era in managing these patients optimally and delineating the patients at further risk of having extra-uterine gestation.

\section{METHODS}

The present study was conducted in Department of Obstetrics and Gynaecology in Vardhaman Mahavir Medical College and Safdarjung hospital over a span of two years from July 2014 to June 2016 under which all patients presenting with a diagnosis of ectopic pregnancy (either ruptured or unruptured) admitted and treated in the institute with expectant, medical or surgical management, were recruited into the study. History, examination findings and risk factors were noted. All the pregnancies were entered into the analysis.

The primary outcome measured was incidence of ectopic pregnancy. The rate of ectopic pregnancy was then calculated as the number of ectopic pregnancies divided by the sum of all ectopic and live birth pregnancies and therapeutic abortions during the period.

For this denominator, all outpatient, inpatient and referral databases described for the identification of ectopic pregnancies was also searched for evidence of live births, ectopic pregnancies, and therapeutic abortions.

Secondary outcomes noted were demographic variables, booking status, predisposing risk factors, antecedent pregnancy event, clinical presentation at admission, complications, need for ICU/HDU admission, expectant management, medical management, surgical management and type of surgery, duration of hospital stay, course in hospital, mortality and cause of death in case of mortality.

Data was recorded on a predesigned proforma and deciphered at the end of study. Data was expressed as Mean \pm 2 SD $(95 \%$ confidence intervals), numbers (percentages) and median (interquartile range) and analysed.

\section{RESULTS}

A total of 51060 pregnant women were included in this study. $420(0.82 \%)$ subjects diagnosed with ectopic pregnancy while 50640 women who delivered or aborted during the same period in the hospital.

Most women were young, with mean \pm standard deviation age of cases was $21.5 \pm 2.8$ years. Mean \pm standard deviation parity in cases was $2.7 \pm 2.25$. Majority (94\%) of the patients were Hindus $(69.52 \%)$, belonging to lower socioeconomic status $(\sim 90 \%)$, hailing from rural areas $(88.33 \%)$ (Table 1$)$.

The factors which appeared to be significantly associated with the risk of ectopic pregnancy were infertility of 2 or more years (10\%), preceding ectopic pregnancy (12.14\%), previous history of PID (29.28\%), TB (21.4\%) previous pelvic surgeries $(18.57 \%)$ and past IUCD use (10.71\%) (Table 2).

Out of all, $7.85 \%$ of patients were asymptomatic, whilst pain abdomen $(76.42 \%)$ followed by irregular vaginal bleeding $(46.42 \%)$, with amenorrhea and shock $(27.14 \%)$ were main clinical symptoms (Table 3 ). 
Table 1: Distribution of women as per maternal and socio-demographic characteristics.

\begin{tabular}{|c|c|c|}
\hline Characteristic & $\begin{array}{l}\text { No. of ectopic } \\
\text { pregnancy, } n=420\end{array}$ & $\%$ \\
\hline \multicolumn{3}{|l|}{ Age (years) } \\
\hline$<20$ & 52 & 12.38 \\
\hline $21-25$ & 243 & 57.86 \\
\hline $26-30$ & 101 & 24.05 \\
\hline $31-35$ & 34 & 8.09 \\
\hline \multicolumn{3}{|l|}{ Gravidity } \\
\hline 1 & 153 & 36.42 \\
\hline 2 & 76 & 18.09 \\
\hline 3 & 88 & 20.95 \\
\hline$\geq 4$ & 114 & 27.14 \\
\hline \multicolumn{3}{|l|}{ Education } \\
\hline Illiterate & 323 & 76.90 \\
\hline Primary & 47 & 11.19 \\
\hline Middle & 10 & 2.38 \\
\hline High school & 25 & 5.95 \\
\hline Secondary & 10 & 2.38 \\
\hline Graduation/postgraduation & 5 & 1.19 \\
\hline \multicolumn{3}{|l|}{ Religion } \\
\hline Hindu & 292 & 69.52 \\
\hline Sikh & 2 & 0.47 \\
\hline Muslim & 12 & 2.86 \\
\hline Christian & 0 & 0 \\
\hline Others & 2 & 0.47 \\
\hline \multicolumn{3}{|l|}{ Address } \\
\hline Urban & 49 & 11.67 \\
\hline Rural & 371 & 88.33 \\
\hline \multicolumn{3}{|l|}{ Socioeconomic status } \\
\hline $\mathrm{i}$ & 0 & 0 \\
\hline ii & 4 & 0.95 \\
\hline iii & 45 & 10.71 \\
\hline iv & 100 & 23.81 \\
\hline $\mathrm{V}$ & 271 & 64.52 \\
\hline \multicolumn{3}{|l|}{ Occupation } \\
\hline Housewife & 410 & 97.62 \\
\hline Working & 10 & 2.38 \\
\hline \multicolumn{3}{|l|}{ Antenatal care } \\
\hline Booked & 69 & 16.43 \\
\hline Un-booked & 351 & 83.57 \\
\hline \multicolumn{3}{|l|}{ BMI } \\
\hline$<18.9$ & 23 & 5.47 \\
\hline $19-24.9$ & 285 & 67.85 \\
\hline $25-29.9$ & 100 & 23.81 \\
\hline $30-34.9$ & 12 & 2.38 \\
\hline $35-39.9$ & 0 & 0 \\
\hline$>40$ & 0 & 0 \\
\hline
\end{tabular}

Main site of ectopic pregnancy came out to be tubal $(80 \%)$ followed by cornual $(7.85 \%)$ in the audit (Table 4).

In the study, $81.19 \%$ women were surgically explored, whereas $18.80 \%$ had conservative management.
Table 2: Prevalence of risk factors among 420 pregnant women with ectopic gestation.

\begin{tabular}{|c|c|c|}
\hline Risk factors & $\begin{array}{l}\text { No. of ectopic } \\
\text { pregnancy, } n\end{array}$ & $\%$ \\
\hline Early age at marriage & 52 & 12.38 \\
\hline Multiparity & 153 & 36.4 \\
\hline History of smoking & 45 & 10.71 \\
\hline Past & 38 & 9.04 \\
\hline Present & 7 & 1.67 \\
\hline Previous ectopic pregnancy & 51 & 12.14 \\
\hline One & 46 & 10.94 \\
\hline Two & 4 & 0.95 \\
\hline$>$ Three & 1 & 0.23 \\
\hline Multiple sexual partners & 13 & 3.09 \\
\hline Fertility treatment & 42 & 10 \\
\hline \multicolumn{3}{|l|}{ Ovulation induction with } \\
\hline Clomiphene citrate & 24 & 5.71 \\
\hline GNRH & 9 & 2.14 \\
\hline IVF & 9 & 2.14 \\
\hline Previous surgical procedures & 78 & 18.57 \\
\hline Tubal ligation & 12 & 2.38 \\
\hline Tubal reconstruction & 24 & 5.71 \\
\hline Other & 42 & 10 \\
\hline $\begin{array}{l}\text { History of tuberculosis } \\
\text { and/or ATT }\end{array}$ & 90 & 21.4 \\
\hline Genital & 12 & 2.38 \\
\hline Extragenital & 78 & 18.57 \\
\hline H/O PID & 123 & 29.28 \\
\hline One episode & 23 & 5.47 \\
\hline Two episodes & 60 & 14.28 \\
\hline$>$ Three episodes & 40 & 9.52 \\
\hline $\begin{array}{l}\text { Previous use of oral } \\
\text { contraceptive }\end{array}$ & 23 & 5.47 \\
\hline $\begin{array}{l}\text { Previous use of intrauterine } \\
\text { device }\end{array}$ & 45 & 10.71 \\
\hline \multicolumn{3}{|c|}{ Time since previous pregnancy } \\
\hline $0-6$ months & 28 & 6.67 \\
\hline 7-12 months & 122 & 29.04 \\
\hline $13-24$ months & 102 & 24.28 \\
\hline $25-36$ months & 4 & 0.95 \\
\hline 37-48 months & 9 & 2.14 \\
\hline $49-60$ months & 2 & 0.47 \\
\hline$\geq 61$ month & 0 & 0 \\
\hline
\end{tabular}

Salpingectomy following exploratory laparotomy was the foremost procedure followed, and around $44.28 \%$ patients underwent dilatation and curettage (Table 5).

Around $16.42 \%$ patients required HDU/ICU admission. Most of the women were discharged in stable condition within 96 hours $(\sim 95 \%)$, whereas 3 women died due to the disease.

Cause of death was congestive failure following severe blood loss in 2 cases, and MODS in one women (Table $6)$. 
Table 3: Distribution of patients as per their clinical presentation and diagnostic profile.

\begin{tabular}{|lll|}
\hline Clinical profile & Cases & \\
\hline Asymptomatic & N & \% \\
\hline Pain abdomen & 331 & 7.85 \\
\hline Irregular vaginal bleeding & 195 & 76.42 \\
\hline Amenorrhea & 87 & 46.42 \\
\hline Features of peritonitis & 96 & 20.71 \\
\hline Shock & 114 & 22.85 \\
\hline Hemo-peritoneum & 294 & 27.14 \\
\hline
\end{tabular}

Table 4: Distribution of patients according to site of ectopic implantation.

\begin{tabular}{|c|c|c|}
\hline Site of ectopic pregnancy & n & $\%$ \\
\hline Tubal & 336 & 80 \\
\hline Cornual & 33 & 7.85 \\
\hline Ovarian & 4 & 0.95 \\
\hline Cervical & 1 & 0.23 \\
\hline Abdominal & 3 & 0.71 \\
\hline Heterotopic & 2 & 0.47 \\
\hline
\end{tabular}

Table 5: Distribution of patients according to management initiated.

\begin{tabular}{|lll|}
\hline Management protocol & Cases & $\%$ \\
\hline Conservative & 79 & 18.80 \\
\hline $\begin{array}{l}\text { Expectant } \\
\text { Medical }\end{array}$ & 28 & 6.67 \\
\hline Surgical & 51 & 12.14 \\
\hline $\begin{array}{l}\text { Exploratory laparotomy } \\
\text { followed by hemo- } \\
\text { peritoneum drainage and }\end{array}$ & 341 & 81.19 \\
\hline Salpingostomy & 5 & 1.19 \\
\hline $\begin{array}{l}\text { Salpingectomy } \\
\text { Salpingo-oophorectomy }\end{array}$ & 285 & 67.85 \\
\hline $\begin{array}{l}\text { Oophorectomy } \\
\text { Cornual pregnancy resection } \\
\text { and anastomosis }\end{array}$ & 45 & 3.57 \\
\hline
\end{tabular}

\section{DISCUSSION}

Though the mortality associated with ectopic pregnancy has come down with years, prompt diagnoses is imperative in decreasing the concomitant morbidity. Lawson Tait who reported the first successful operation for ectopic pregnancy in 1883, also had tough times in establishing the diagnosis of ectopic gestation. ${ }^{22}$ Thus emphasis should be laid on making young doctors well equipped with picking up and appropriately managing this life-threatening emergency.

Table 7 displays a comparative evaluation of studies done by past pollsters on ectopic pregnancy across the world with the findings of the present study. This study reinforces the fact that the mean annual rate of ectopic pregnancy is on the rise. Incidence of ectopic gestation in present study was 1:120 deliveries in two years. It is quite comparable, when compared to that deduced by most of the recent authors. ${ }^{23-27}$ However its lower when compared to work done by Stulberg DB et al $(2.22 \%)$, Prassana B et al $(1.8 \%)$ and Musa et al $(1.74 \%){ }^{4,18,28}$ This can be attributed to the relatively younger study population (with lesser incidence of ectopic gestation) in the present study as opposed to others, and inclusion of elective abortions in our denominator of total pregnancies.

Table 6: Course in hospital.

\begin{tabular}{|c|c|c|}
\hline \multirow{2}{*}{ Course in the hospital } & \multicolumn{2}{|l|}{ Cases } \\
\hline & $\mathrm{N}=\mathbf{4 2 0}$ & $\%$ \\
\hline ICU/HDU admission & 69 & 16.42 \\
\hline \multicolumn{3}{|l|}{ Duration of hospital stay } \\
\hline$<48$ hours & 64 & 15.23 \\
\hline 48-96 hours & 345 & 82.14 \\
\hline$>96$ hours & 11 & 2.62 \\
\hline \multicolumn{3}{|l|}{ Fate in hospital } \\
\hline Recovered and discharged & 401 & 95.47 \\
\hline Died & 3 & 0.71 \\
\hline LAMA & 15 & 3.57 \\
\hline Relaparotomy & 1 & 0.23 \\
\hline \multicolumn{3}{|c|}{ Cause of death in case of mortality } \\
\hline $\begin{array}{l}\text { Congestive failure due to } \\
\text { severe anaemia }\end{array}$ & 2 & 0.47 \\
\hline $\mathrm{DIC}$ & 0 & 0 \\
\hline MODS & 1 & 0.23 \\
\hline Any other & 0 & 0 \\
\hline Dilatation and curettage & 186 & 44.28 \\
\hline
\end{tabular}

Most women in the present study were young multiparas, following Hinduism (69.52\%), belonging to lower socioeconomic status $(\sim 90 \%)$, hailing from rural areas $(88.33 \%)$. This reflects largely the population to which the study hospital largely caters to. Also, weighing the relatively younger age against previous research studies from west, a moderately juvenile population in the present study designates early age, both at tying the nuptial knot and conception in India, especially study population. . $^{4,7,29-32}$

The higher incidence in multiparas is also consistent with findings in other studies. ${ }^{4-7,23-28}$ The postulated mechanism includes vicissitudes in tubal configuration and function through age, in addition to recurrent or subclinical episodes of PID or post-abortal sepsis in such females that befall over time instigating progressively ruinous tubal damage. However, the conclusions differed from those of Majhi et al (smaller study) showing increasing extra-uterine pregnancy in primiparas. ${ }^{29}$

Furthermore, low socioeconomic status itself adds to the risk for having an extra-uterine pregnancy in these women, owing to poor cleanliness and greater risk of PID. Maximum females came as referral cases from nearby rural peripheral centers without any prior antenatal supervision. This points out to a prevalent 
dearth of awareness among women and failure on their part to access to primary health care, besides lack of expertise in diagnosing and managing such common emergency conditions at the grass-root level.

Table 7: Comparison of observations between various recent studies on extra uterine pregnancy.

\begin{tabular}{|c|c|c|c|c|}
\hline Author & $\begin{array}{l}\text { Study type/duration } \\
\text { (years) }\end{array}$ & $\begin{array}{l}\text { Outcomes } \\
\text { studied }\end{array}$ & $\begin{array}{l}\text { Incidence of ectopic } \\
\text { /sample size }\end{array}$ & Conclusions \\
\hline Bouyer et al ${ }^{10}$ & $\begin{array}{l}\text { Case control/7 } \\
\text { years }\end{array}$ & $\begin{array}{l}\text { Risk factors } \\
\text { only }\end{array}$ & 803 cases taken & $\begin{array}{l}\text { Infectious history and smoking main } \\
\text { risk factors }\end{array}$ \\
\hline Karen $\mathrm{W}$ et $\mathrm{al}^{38}$ & $\begin{array}{l}\text { Retrospective } / 5 \\
\text { years }\end{array}$ & $\begin{array}{l}\text { Incidence and } \\
\text { trends }\end{array}$ & $0.64 \%$ & $\begin{array}{l}\text { Surgical management decreased } \\
\text { from } 40 \text { to } 33.1 \% \text {, medical } \\
\text { management increased from } 11.1 \text { to } \\
35.1 \%\end{array}$ \\
\hline $\begin{array}{l}\text { Andrea A et } \\
\mathrm{al}^{39}\end{array}$ & $\begin{array}{l}\text { Retrospective/27 } \\
\text { year }\end{array}$ & $\begin{array}{l}\text { Mortality } \\
\text { trends }\end{array}$ & $\begin{array}{l}876 \text { deaths due to } \\
\text { ectopic }\end{array}$ & Decline in mortality over these years \\
\hline Stulberg et $\mathrm{al}^{4}$ & $\begin{array}{l}\text { Retrospective/4year } \\
\text { multicentric }\end{array}$ & $\begin{array}{l}\text { Incidence, } \\
\text { demography }\end{array}$ & 2.08 to $2.43 \%$ & $\begin{array}{l}\text { Increased risk in black and older } \\
\text { women }\end{array}$ \\
\hline Vasvani $\mathrm{P}$ et $\mathrm{al}^{7}$ & $\begin{array}{l}\text { Case control / } 3 \\
\text { year }\end{array}$ & Risk factors & $\begin{array}{l}100 \text { cases, } 216 \\
\text { controls }\end{array}$ & $\begin{array}{l}\text { PID 8x; Infertility 6x; Pelvic } \\
\text { surgeries 3x }\end{array}$ \\
\hline $\begin{array}{l}\text { Pathiraja P et } \\
\mathrm{al}^{20}\end{array}$ & $\begin{array}{l}\text { Retrospective } 2 \\
\text { centre / } 6 \text { months }\end{array}$ & $\begin{array}{l}\text { Surgical } \\
\text { management } \\
\text { only }\end{array}$ & 20 cases & 7 laparoscopic; 13 laparotomies \\
\hline $\begin{array}{l}\text { Murugesan et } \\
\mathrm{al}^{26}\end{array}$ & $\begin{array}{l}\text { Retrospective } / 3 \\
\text { years }\end{array}$ & $\begin{array}{l}\text { Outcome and } \\
\text { risk factors }\end{array}$ & $1.77 \%$ & $\begin{array}{l}73 \% \text { had risk factors, } 100 \% \\
\text { surgical management; tubal } \\
\text { surgery } 31.15 \%\end{array}$ \\
\hline Suseela et $\mathrm{al}^{37}$ & Prospective/2 years & $\begin{array}{l}\text { Management } \\
\text { and morbidity }\end{array}$ & 50 cases & $\begin{array}{l}90 \% \text { surgical management, } 4 \% \text { ICU } \\
\text { admission }\end{array}$ \\
\hline $\begin{array}{l}\text { Yadav DP et } \\
\mathrm{al}^{40}\end{array}$ & Prospective/2 year & $\begin{array}{l}\text { Risk factors } \\
\text { and outcome }\end{array}$ & 80 cases & $\begin{array}{l}\text { PID most common followed by } \\
\text { pelvic surgeries }\end{array}$ \\
\hline Present Study & $\begin{array}{l}\text { Retrospective / } 2 \\
\text { year }\end{array}$ & $\begin{array}{l}\text { Risk factors, } \\
\text { Clinical profile, } \\
\text { management, } \\
\text { morbidity, } \\
\text { mortality }\end{array}$ & $0.82 \%$ & $\begin{array}{l}\text { Significant factors=PID, TB, pelvic } \\
\text { surgeries and prior ectopic. } 81.19 \% \\
\text { surgically explored, three women } \\
\text { died. }\end{array}$ \\
\hline
\end{tabular}

Despite technological evolutions in medical sciences, exact etiology of ectopic gestation is still unknown. Familiarity and passable comprehension of associated risk factors, and their identification in an individual patient, appears quintessential for prompt diagnosis.

In consonance with earlier studies demonstrating a likelihood ratio of around 7-9 times of ectopic in women with past history of pelvic infection, the most common risk factor in the extant study also was infectious morbidity previous history of PID (29.28\%), and history of TB $(21.4 \%) .^{4,5,7,18,23-28}$ This can be ascribed to the fact that the resulting fibrosis after the resolution of the inflammatory process, causes distortion of the fallopian tubes, narrowing of tubal lumen or intratubal adhesions. These alterations in turn impede the passage of the ovum, favoring implantation in blind pockets of adhesions. ${ }^{18,27-29}$ Thus the post inflammatory damage acts as a two-way sword, by causing reduction of chances of conception leading to diminished fertility, and at the same time predisposing the woman to tubal pregnancy. The trend of early marriages, coupled with lack of knowledge regarding sexual health, and social taboos associated with it, the consortium of women studies is predisposed to infectious morbidity including sexually transmitted infections. Thus, the clinicians especially gynecologists need to promote health education and encourage safe sexual practices in the community, besides treating both partners for thorough alleviation of the same.

Also, the contribution of chronic impairment of the reproductive function predisposing to ectopic pregnancy can be demonstrated in the current study by the increased chances of recurrence of ectopic pregnancy among women who have had an ectopic pregnancy in the past, similar to many studies. ${ }^{4,5,7,18,23-30,32}$

Past pelvic surgery favoring adhesion formation and distortion of tubal anatomy predisposes the woman to have extra-uterine implantation. ${ }^{4,5,7,18,23-37}$ This reiterates the fact that ectopic pregnancy should be strongly thought of in a woman with previous history of tubal surgery 
presenting with acute pain abdomen with or without amenorrhea or fainting attack. ${ }^{23-37}$

Akin to few researchers of west, past and present history of smoking was found in $\sim 10 \%$ women of ectopic pregnancy in the present study. $4,18,23-31$

The risk of ectopic pregnancy was also found increased with an intrauterine device similar to previous investigators (upto 10-fold). ${ }^{4,18,23-30,35-37}$ This could be due to IUD-induced inflammation resulting in declination of the endosalpinx and delays in ovum transport causing extra-uterine implantation.

Also, it has been observed in the past, that with increase in duration of infertility the crude risk for ectopic pregnancy increases., ${ }^{48,23-30,36,37}$ Analogously, women having infertility and ovulation induction had ectopic pregnancy, though this significance needs further assessment

Also, previous abortions also had a causal effect, possibly mediated by infection, akin to previous studies. ${ }^{34,37}$ The etiological hypothesis could be chromosomal aberrations or hormonal factors, but both of these require further evaluation. ${ }^{4,18}$

Pain abdomen $(76.42 \%)$ followed by irregular vaginal bleeding $(46.42 \%)$, with amenorrhea and shock $(27.14 \%)$ were main clinical symptoms in the present study. This spectrum was a little different from previous investigators suggesting that women, and their kith and kin still ignore minor irregularities in bleeding patterns and amenorrhea until pain abdomen incapacitates them from performing household work. ${ }^{4,18,23-27}$ Also, a high incidence of shock, akin to study of Majhi et al, again highlights the lack of antenatal care and neglect in Indian rural women. ${ }^{29}$ This issue needs to be addressed with great perseverance by the family, clinicians and the policy makers in order to draw more antenatal women for early booking and ultrasound to detect nonviable gestation and ruling out ectopic before it causes the catastrophe in woman.

Main site of implantation in the audit was tubal (80\%).

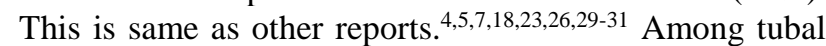
pregnancies, $90 \%$ were ruptured and only $10 \%$ were unruptured. This high rate of ruptured ectopic pregnancies found in this study establishes the felt need to change the poor health-seeking behavior of local people, in terms of accessing health care facilities, in order to expedite diagnosis and facilitate early initiation of treatment.

Management of extra-uterine pregnancy includes medical, and surgical treatment, decision being individualized, depending on the hemodynamic condition of the patient, period of gestation, site of ectopic, beta HCG levels and most importantly availability of expertise and required resources in low resource settings like India. The ultimate intention to treat is preservation of maternal life and conservancy of her reproductive capacity.
There was a surprisingly low proportion of cases $(\sim 12 \%)$ that were managed medically as opposed to western literature. This occurred as most of the patients presented late to the hospital in a moribund state, and hence could not be offered these modern management options. Still, those falling under the gamut of medical management, were treated with methotrexate single dose regimen, whilst $6.67 \%$ women were managed expectantly by following beta HCG levels serially. As an essential health care measure with an emphasis on cost savings, it is expected that slowly rising trend to deploy medical management to be persistent in years to come in India.

Also, unlike western countries, laparoscopic surgery could not be provided to women due to clinical profile of patients at the time of admission. Amongst those who were surgically explored, $(81.19 \%)$ the most common surgery performed were total unilateral salpingectomy, especially in presence of a macroscopically normal contralateral tube, similar to popular recommendations worldwide. $^{4,18,23-28}$ Surgical morbidity included anemia, urinary tract infections and wound infection in the present study.

Anemia, which was the commonest (90\%) complication, was due to excessive blood loss from the ruptured site, owing to significant delay in seeking medical care. However, it was managed well at the health facility owing to a 24 hour blood bank services available at the institute with ready availability of screened blood and blood products as required. Though $95 \%$ of the women were discharged in stable condition within 96 hours, 3 women died following ectopic pregnancy during the study period. Analyzing these three mortalities, they were all referred cases with significant delay in going to first referral units (FRUs) and lack of prompt transport facilities to reach our institute in time. Hemorrhagic shock was the chief factor in two of these women followed by multi-organ failure. All these findings reiterate the necessity to augment the health system by snowballing community awareness towards maternal health and endorsing utilization of health care facilities, bolstering the proficient expertise and infrastructure at FRUs including availability of blood bank, and modifying the lags in transport facilities between various facilities. These are the limiting steps in the process of decreasing preventable morbidity due to ectopic gestation in the nation. Furthermore, they would be instrumental in making our country achieve the designated sustainable health goals by the stipulated time.

The guestimates of ectopic pregnancy in the present study, having been made from a relatively smaller study population spanned over a small duration of two years might not be generalizable to all women in the nation. Also, the retrospective nature of the audit poses a kerb as it is restrained by the preciseness and comprehensiveness of data that had been inputted in the case sheets, especially with respect to risk factors. Also, this being a single-centered facility based audit, it cannot reflect data 
at national level completely, as morbidity and mortality occurring in community would still be missing.

\section{CONCLUSION}

Extra-uterine pregnancy still remains a gynaecological catastrophe in developing country like India and a major challenge to the reproductive performance of women worldwide. By reducing and identifying the most frequent risk factors like PID and post abortion sepsis, and detecting the patients at the earliest it is possible to decrease the incidence. This necessitates wide-spread health education on safe sex from the early years of life, and provision of adequate family planning services, such as condoms and other barrier contraceptives. With its rising incidence, it is necessary to devise means of early detection and treatment. Early access to health care facility at the onset of symptoms for thorough clinical evaluation and embarking on appropriate investigations, especially in patients with high suspicion should be undertaken for timely provision of modern conservative therapeutic modalities, aiming at enhanced fecundity along-with prevention of complications associated with surgery.

\section{Recommendations}

The setting up of early pregnancy units in the community to encourage early booking and hence diagnosis of ectopic pregnancy, deployment of new-fangled technologies like mobile health to increase the scope of accessible essential obstetric and family planning services in each household. This audit also highlights the need to maintain an ectopic registry as a useful tool to monitor trends and provide improved understanding of the predicament and fertility issues following management in a local setting. Furthermore, larger powered prospective studies over a bigger duration, especially drawing comparison of risk factors prevalence in normal antenatal patients are recommended to get a better grasp of the causal association of risk factors with ectopic gestation, in order to take adequate steps to ameliorate them.

\section{ACKNOWLEDGMENTS}

Authors are thankful to patients who had experienced this clinical entity and thus enabled them comprehensive analysis of the clinical entity.

\section{Funding: No funding sources}

Conflict of interest: None declared

Ethical approval: The study was approved by the Institutional Ethics Committee

\section{REFERENCES}

1. Takai IU, Yakasai IA, Joy OI, Ugwa EA. An audit of gynaecological procedures performed at Aminu Kano Teaching Hospital. Kano J Basic Clinical Reproductive Sci. 2015;4(2):64-9.
2. Donald L, Fylstra MD. Ectopic pregnancy not within the (distal) fallopian tube: etiology, diagnosis, and treatment. AJOG. 2012;206(4):289-99.

3. Fernandez H, Capmas P, Lucot JP, Resch B, Panel P, Buouer J. Fertility after ectopic pregnancy: the DEMETER randomized trial. Human Reproduction 2013;28(5):1247-53.

4. Stulberg DB, Cain LR, Dahlquist I, Lauderdale DS. Ectopic pregnancy rates in the Medicaid population. Am J Obset Gynecol. 2013;208:274.e1-7.

5. Barnhart KT. Clinical practice. Ectopic pregnancy. N Engl J Med. 2009;361:379-87.

6. Marwah S, Gupta S. Spontaneous Bilateral tubal gestation: a rare case report. Case Reports in Obstet Gynecol. 2016:8526903.

7. Vaswani P, Vaswani R. Evaluation of risk factors for ectopic pregnancy among women attending a tertiary care hospital in United Arab Emirates: a case control study. Sri Lanka J Obstet Gynaecol. 2013;35(2):537.

8. Aziz S, Al-Wafi B, Swadi HA. Frequency of ectopic pregnancy in a medical centre, Kingdom of Saudi Arabia. J Pak Med Assoc. 2011;61(3):221-4

9. Aboyeji AP, Fawole AA, Ijaiya MA. Trends in ectopic pregnancy in Ilorin, Nigeria. Nigerian J Surg Res. 2002;4(1-2):6-10.

10. Bouyer J, Coste J, Shojaei T, Pouly JL, Fernandez H, Gerbaud L, et al. Risk Factors for ectopic pregnancy: a comprehensive analysis based on a large casecontrol, population-based study in France. Am J Epidemiol. 2003;157:185-94.

11. Farquhar CM. Ectopic Pregnancy. The Lancet. 2005;366:583-91.

12. Abasiattai AM, Utuk MN, Ugege W. Spontaneous heterotropic pregnancy with tubal rupture and delivery of a live baby at term: a case report. Nigerian J Med. 2010;19(2):236-8.

13. Mutihir JT, Nyango DD. Massive Haemoperitoneum from endometriosis masquerading as ruptured ectopic pregnancy: case report. Nigerian J Clin Practice. 2010;13(4):477-9.

14. Kirk E, Papageorghious AT, Condous G, Tan L. The diagnostic effectiveness of a initial transvaginal scan in detecting ectopic pregnancy. Hum Reprod. 2007;22:2814-28.

15. Erondu FO, Okoro CR, Aniemeka JI, Ugwu AC, Ohuegbe CI. Atypical clinical sonographic presentation of ectopic pregnancy: a case report. J Med Med Sci. 2010;1(4):5.

16. Cohen A, Zakar L, Gil Y, Amer-Alshiek J, Bibi G, Almog B, et al. Methotrexate success rates in progressing ectopic pregnancies: A reappraisal. Am J Obstet Gynecol. 2014;211(2):128.e1-5.

17. Bangsgaard N, Lund CO, Ottesen B, Nilas L. Improved fertility following conservative surgical treatment of ectopic pregnancy. BJOG. 2003;110:765-70.

18. Musa J, Daru PH, Mutihir JT, Ujah IAO. ectopic pregnancy in Jos Northern Nigeria: prevalence and 
impact on subsequent fertility. Nigerian $\mathbf{J}$ Med. 2009; 18:35-8.

19. Dabota BY. Management and outcome of ectopic pregnancy in developing countries. Ectopic Pregnancy Modern Diagn Manag. Edited by Kamrava M (Ed.); Intech publisher;2011:109-136.

20. Pathiraja RP, Jayawardane MAMM, Silva KCDP, Srisanjeevan S. An audit on surgical management of Tubal ectopic pregnancies and patients' preferences survey. Sri Lanka J Obstet Gynecol. 2015;6:19-21.

21. Mol F, Mello NMV, Strandell A, Strandell K, Jurkovic D, Ross J, et al. Salpingotomy versus salpingectomy in women with tubal pregnancy (ESEP study): an open-label, multicentre, randomized controlled trial. Lancet. 2014;383(9927):1483-9.

22. Tait RL. Five cases of extrauterine pregnancy operated upon at the time of rupture. BMJ. 1884;1:1250-51.

23. Wakankar R, Kedar K. Ectopic Pregnancy: a rising Trend. Int J Sci Stud. 2015;3(5):18-22.

24. Gaddagi RA, Chandrashekhar AP. a clinical study of ectopic pregnancy. J Clin Diagn Res. 2012;6(5):8679.

25. Tuli AG, Goyal S, Livingston D, Kurian AS. Ectopic pregnancy: a five-year retrospective study in a tertiary care hospital. Int J Reprod Contracept Obstet Gynecol. 2015;4(5):1400-3.

26. Murugusen A, Prabhu K, Muthulakshmi M. A retrospective study of ectopic pregnancies in a tertiary care hospital. Int J Reprod Contracept Obstet Gynecol. 2016;5(8):2537-40.

27. Singh S, Mahendra G, Vijayalakshmi S, Pukale RS. Clinical study of ectopic pregnancy in a rural setup: a two-year survey. Nat J Med Res. 2014;4(1):37-9.

28. Prasanna B, Jhansi CB, Swathi K, Shaik MV. A study on risk factors and clinical presentation of ectopic pregnancy in women attending a tertiary care centre. IAIM. 2016;3(1):90-6.

29. Majhi AK, Roy N, Karmakar KS, Banerjee PK. Ectopic pregnancy: an analysis of 180 cases. J Indian Med Assoc. 2007;105(6):308-12.

30. Yakasai IA, Abdullahi J, Abubakar IS. Management of ectopic pregnancy in Aminu Kano teaching hospital Kano Nigeria: A 3 year. Global Advanced Res J Med Med Sci. 2012;1(7):181-5.

31. Igwegbe AO, Eleje GU, Okpola BC. An appraisal of the management of ectopic pregnancy in a Nigerian Tertiary Hospital. Ann Med Health Science Res. 2013;3(2):166-70.

32. Onwuhafua PI, Onwuhafua A, Adesiyun GA, Adze J. Ectopic pregnancies at Ahmadu Bello University Teaching Hospital, Kaduna Northern Nigeria. Trop J Obstet Gynecol. 2001;18:82-6.

33. Shetty S, Shetty A. A clinical Study of ectopic pregnancies in a tertiary care hospital of Mangalore, India. Innovative J Med Health Sci. 2014;4(1):305-9.

34. Mufti S, Rather S, Mufti S, Rangrez RA, Wasiqa, Khalida. Ectopic pregnancy: an analysis of 114 cases. JK Practitioner. 2012;17(4):20-3.

35. Panchal D, Vaishnav G, Solanki K. Study of management in patient with ectopic pregnancy. NJIRM. 2011;2(3):91-4.

36. Asuri SS, Kalpana P. A clinical study of ectopic pregnancy. IJRCOG. 2016;5(11):3750-3.

37. Suseela TL, Gunakala KC. A study on management, morbidity and mortality of ectopic pregnancy attending a tertiary care centre at Rajiv Gandhi Institute of Medical Sciences General Hospital, Kadapa, Andhra Pradesh, India. IJRCOG. 2016;5(11):3736-9.

38. Hoover KW, Tao G, Kent CK. Trends in the diagnosis and treatment of ectopic pregnancy in the United States. Obstet Gynecol. 2010;115(3):495-502.

39. Andrea A, Creanga MD, Shapiro-Mendoza CK, Bish CL, Zane S, Berg CJ, et al. Trends in ectopic pregnancy mortality in the United States 1980-2007. Obstet Gynecol. 2011;117(4):837-43.

40. Yadav DP, Bhati I, Bhati BS. Ectopic pregnancy: a comprehensive analysis of risk factors and management. Int $\mathbf{J}$ Reprod Contracept Obstet Gynecol. 2016;5(8):2723-7.

Cite this article as: Marwah S, Rani KU, Mishra A. An audit of extra-uterine pregnancy in a tertiary care facility in Northern India. Int J Reprod Contracept Obstet Gynecol 2017;6:5025-32. 